\title{
ANALISIS UJI AKURASI MODEL GROVER, SPRINGATE, DAN ZMIJEWSKI DALAM MEMPREDIKSI KEBANGKRUTAN PERUSAHAAN DELISTED DI BEI
}

\author{
Komang Agus Rudi Indra Laksmana1, Ayu Darmawati \\ ${ }^{1}$ Universitas Mahendradatta, Denpasar, Indonesia. Email : (ilaksmana70@gmail.com) \\ ${ }^{2}$ Universitas Mahendradatta, Denpasar, Indonesia
}

\begin{tabular}{|c|c|}
\hline ARTICLE INFO & ABSTRACT \\
\hline $\begin{array}{l}\text { Keywords: } \\
\text { Financial Distress, Grover, Springate, } \\
\text { Zmijewski Models } \\
\text { Financial Distress, Model Grover, } \\
\text { Springate, Zmijewski } \\
\text { How to cite: } \\
\text { Laksmana, Komang Agus RI., Darmawati, } \\
\text { Ayu. (2019). Analisis Uji Akurasi Model } \\
\text { Grover, Springate, Dan Zmijewski Dalam } \\
\text { Memprediksi Kebangkrutan Perusahaan } \\
\text { Delisted Di Bei. JMM UNRAM, 8(1), } 62 \text { - } \\
72 \\
\text { DOI: } \\
\text { 10.29303/jmm.v8i1.409 }\end{array}$ & $\begin{array}{l}\text { This study aimed at analyzing how the results of the } \\
\text { Grover, Springate and Zmijewski models predict the } \\
\text { bankruptcy of PT Citra Maharlika Nusantara Corpora Tbk for } \\
\text { the period of June } 2013 \text { - September 2016. This study also } \\
\text { aimed at measuring the accuracy of the bankruptcy prediction } \\
\text { model and determined which predictive model of the three } \\
\text { models was the most accurate. From the data analysis, it was } \\
\text { found that Springate model was the most accurate prediction } \\
\text { model with 100\% accuracy rate to predict the bankruptcy of PT } \\
\text { Citra Maharlika Nusantara Corpora Tbk compared to the } \\
\text { Grover model with an accuracy rate of } 71.48 \% \text { and Zmijewski } \\
\text { model with the lowest accuracy rate of } 21.48 \% \text {. The limitations } \\
\text { of this study was this study only carried out in one company, } \\
\text { thus in the future it is expected that the model will be tested in } \\
\text { more than one company and type of business sector. } \\
\text { Penelitian ini bertujuan untuk menganalisis } \\
\text { bagaimana hasil dari model Grover, Springate dan } \\
\text { Zmijewski dalam memprediksi kebangkrutan PT Citra } \\
\text { Maharlika Nusantara Corpora Tbk periode Juni } 2013- \\
\text { September } 2016 \text { serta mengukur tingkat akurasi model } \\
\text { prediksi kebangkrutan tersebut dan menentukan model } \\
\text { prediksi manakah diantara ketiga model tersebut yang } \\
\text { paling akurat. Model Springate menjadi model prediksi } \\
\text { paling akurat dengan tingkat akurasi 100\% untuk } \\
\text { memprediksi kebangkrutan PT Citra Maharlika } \\
\text { Nusantara Corpora Tbk dibandingakan dengan model } \\
\text { Grover dengan tingkat akurasi } 71,48 \% \text { dan model } \\
\text { Zmijewski dengan tingkat akurasi paling rendah sebesar } \\
\text { 21,48\%.Keterbatasan penelitian ini terletak pada } \\
\text { pengujian model pada satu perusahaan di satu unit }\end{array}$ \\
\hline
\end{tabular}

jmm.unram.ac.id 
sektor usaha, kedepan bisa dilakukan pengujian pada berbagai jenis sektor usaha.

Copyright (C) 2019 JMM UNRAM. All rights reserved.

\section{PENDAHULUAN}

Salah satu tanggung jawab perusahaan adalah menghasilkan kinerja yang baik agar terhindari dari financial distress. Terdapat beberapa pendapat tentang Financial Distress yang menyamakan Financial Distress dengan kebangkrutan. Namun pada dasarnya hal ini berbeda, Financial Distress merupakan salah satu penyebab terjadinya kebangkrutan dalam hal keuangan perusahaan sedangkan masih banyak faktor-faktor diluar keuangan yang dapat menyebabkan kebangkrutan perusahaan. Setiap perusahaan yang mengalami Financial Distress tidak selalu akan mengalami kebangkrutan, tergantung dari pihak manajemen bisa mengatasi permasalahan ini atau tidak, karena pada dasarnya hal ini merupakan sinyal kebangkrutan suatu perusahaan. Istilah umum untuk menggambarkan situasi tersebut adalah kebangkrutan, kegagalan, ketidakmampuan melunasi hutang, default/perusahaan yang melanggar peraturan dengan kreditor dan bisa dikenakan hukuman. (Atmini danWuryana dalam Ilmi, 2016). Munawir (2002:289) menjelaskan bahwa penyebab kebangkrutan pada dasarnya dapat disebabkan oleh faktor internal maupun faktor eksternal perusahaan, baik yang bersifat khusus yang berkaitan langsung dengan perusahaan maupun yang bersifat umum.

Indikator perusahaan mengalami financial distress adalah delisted dari pasar modal. Delisted merupakan salah satu indikator perusahaan bangkrut di pasar modal (Hadi dan Anggraeni, 2008). Delisting adalah penghapusan pencatatan saham emiten dari bursa. Penghapusan Efek tersebut dinilai mengalami trend negatif secara financial atau bangkrut, hal ini berpotensi dikeluarkan secara paksa dari pencatatan di bursa saham yang di terbitkan oleh Bursa Efek Indonesia.

Berdasarkan data dari Bursa Efek Indonesia tahun 2017 ada 8 perusahaan yang terdaftar di Bursa Efek Indonesia yang harus di delisting oleh Bursa Efek Indonesia. Berdasarkan dari data, banyaknya perusahaan yang mengalami delisting dikarenakan oleh berbagai hal seperti kondisi perusahaan yang berpengaruhnegatif terhadap perusahaan, go private, merger dengan perusahaan lain, dan adajuga yang dikarenakan pailitatau bangkrut. Salah satunya yaitu sub sektortransportasi, PT Citra Maharlika Nusantara Corpora Tbk.

PT. Citra Maharlika Nusantara Corpora Tbk (CPGT) semula bernama PT. Cipaganti Cipta Graha Tbk merupakan perusahaan publik yang bergerak dalam bidang jasa khususnya transportasi yang didirikan pada tahun 1985 dinyatakan delisting oleh Bursa Efek Indonesia sejak tanggal 19 Oktober 2017. Hal tersebut dikarenakan CPGT dinyatakan pailit lantaran tidak berhasil meyakinkan kreditur atas proposal perdamaian. Dalam agenda pemungutan suara, sembilan kreditur separatis menyatakan menolak proposal perdamaian CPGT. Kesembilan separatis tersebut mewakili tagihan Rp164,7 miliar dari 47 kreditur yang hadir dengan total tagihan senilai Rp245 miliar (www.kabar24.com, 2 Mei 2017).

Potensi kebangkrutan dapat diketahui dari nilai atau index yang dihitung melalui metode prediksi kebangkrutan. Diantaranya adalah metode Springate Model oleh Gordon L.V. Springate (1978) dari Kanada, Datastream's model oleh Marais (UK, 1979), Fulmer Model (US, 1984), Ca-score (Kanada, 1987), model logistical regression oleh Ohlson (1980), model artificial 


\section{NATIONALLY ACCREDITED JOURNAL - DECREE NO. 21/E/KPT/2018}

neural network oleh Thomaidis et al. (1998), Hsieh et al. (2006), Model Altman (1968), model Grover, model Zmijewski, dan lain - lainya.Beberapa penelitian terdahulu dalam pengujian akurasi memiliki hasil yang berbeda, penelitian dari Bimawiratma (2016) dan Prihantini et, al (2013) menemukan bahwa model Grover memiliki akurasi yang paling baik diantara model lainnya. Namun, penelitian dari Permana dkk (2017), Priambodo (2017) dan Sari (2014) menemukan bahwa model Springate memiliki tingkat akurasi yang paling baik diantara model lainnya. Sedangkan penelitian dari Fatmawati (2012) menemukan bahwa model Zmijewski memiliki tingkat akurasi yang paling baik bila dibandingkan dengan model lainnya.

Perbedaan hasil penelitian terdahulu disebabkan karena pada dasarnya setiap model memiliki karakteristik yang berbeda. Suatu model mungkin tepat untuk jenis perusahaan tertentu namun kemungkinan tidak tepat untuk jenis perusahaan lainya. Perbedaan hasil penelitian (research gap) terdahulu menjadi dasar untuk melakukan penelitian guna menguji model prediksi kebangkrutan perusahaan yang paling akurat. Penelitian ini akan menguji kembali tingkat akurasi model prediksi kebangkrutan yang digunakan yaitu model Grover, model Springate, dan model Zmijewski untuk memprediksi kebangkrutan PT Citra Maharlika Nusantara Corpora Tbk yang terdaftar di Bursa Efek Indonesia untuk tahun buku 2013-2016.

\section{TELAAH LITERATUR}

\section{Kesulitan Keuangan (Financial Distress)}

Faktor yang menjadi kunci dalam mengidentifikasi apakah perusahaan berada dalam kondisi Financial Distress adalah kondisi dimana perusahaan mengalami laba bersih operasi (net operation income) negatif selama beberapa tahun dan selama lebih dari satu tahun tidak melakukan pembayaran dividen, pemberhentian tenaga kerja atau menghilangkan pembayaran dividen (Almilia, dkk, 2003).

Kesulitan keuangan dimulai ketika perusahaan tidak dapat memenuhi jadwal pembayaran atau ketika proyeksi arus kas mengindikasikan bahwa perusahaan tersebutakan segera tidak dapat memenuhi kewajibannya (BrighamdanDaves, 2010). Ada beberapa definisi kesulitan keuangan, sesuai tipenya, yaitu economic failure, business failure, technical insolvency, insolvency inbankruptcy, dan legal bankruptcy (Brigham dan Gapenski, 1997).

a. EconomicFailure, kegagalan ekonomi adalah keadaan dimana pendapatan perusahaan tidak dapat menutupi total biaya, termasuk cost of capital.

b. Business Failure, kegagalan bisnis didefinisikan sebagai bisnis yang menghentikan operasi dengan akibat kerugian kepada kreditur.

c. Technical Insolvency, sebuah perusahaan dikatakan dalam keadaan technical insolvency jika tidak dapat memenuhi kewajiban lancar ketika jatuh tempo.

d. Insolvencyin Bankruptcy, sebuah perusahaan dikatakan dalam keadaan Insolventin Bankruptcy jika nilai buku hutang melebihi nilai pasar aset.

e. Legal Bankruptcy, perusahaan dikatakan bangkrut secara hukum jika telah diajukan tuntutan secara resmi dengan undang-undang (Brigham dan Gapenski, 1997).

\section{Indikator Kesulitan Keuangan (Financial Distress)}

Elloumi dan Gueyie (2001) mengkategorikan suatu perusahaan sedang mengalami financial distress jika perusahaan tersebut selama dua tahun berturut-turut mempunyai laba bersih negatif. Almilia, dkk(2003) menyatakan bahwa perusahaanyang mengalami financial distress adalah perusahaan yang selama beberapa tahun mengalami laba bersih operasi (net 
operating income) negatif dan selama lebih dari satu tahun tidak melakukan pembayaran deviden.

\section{Dasar Hukum Kepailitan}

Amerika menerbitkan legal bankruptcy yang diatur dalam Chapter 7 Bankruptcy Code tentang liquidation bankruptcy yang merinci prosedur dalam melikuidasi perusahaan. Dalam hal ini pengadilan menunjuk wali (trustee), yang mengumpulkan properti perusahaan, mengurangi kas, dan mendistribusikan kelebihan pada kreditur dengan dasar prorata dengan secepat dan seefisien mungkin. Distribusi aset yang rapi dan adil kepada kreditur akan dapat mengurangi dampak negatif dari kegagalan bisnis. Untuk perusahaan kesulitan keuangan yang enggan menyerah dan berusaha meraih survive, aturannya terdapat dalam Chapter 11 Bankruptcy Code.

Perusahaan akan berusaha untuk meyakinkan kreditur agar membekukan klaimnya untuk sementara selagi perusahaan tersebut melakukan reorganisasi dan membangun kembali operasi sampai diraih laba yang memuaskan. Pendekatan reorganisasi kebangkrutan ini dapat dilakukan berdasarkan kemampuan perusahaan meyakinkan kreditur bahwa ia dapat berhasil dipasar dengan mengimplementasikan strategi perencanaan baru. Ketika menghasilkan laba, perusahaan dapat membayar kembali kreditur, barangkali secara penuh. Jadi, chapter 11 Bankruptcy Code dilakukan jika ada peluang kemungkinan hidup jangka panjang secaranyata. Chapter 11 memberi waktu dan perlindungan bagi debitur perusahaan untuk reorganisasi dan menggunakan pendapatan mendatang guna membayar kreditur.

Perusahaan mungkin merestrukturiasi hutang, menutup divisi atau toko yang tidak profitable, menegosiasikan kembali kontrak pekerja, mengurangi kekuatan pekerjaan, atau mengajukan tindakan lain yang dapat menciptakan bisnis yang lebih menguntungkan. Jika rencana disetujui kreditur, perusahaanakan diberi peluang lain untuk menghindari likuidasi dan lahir kembali dari kebangkrutan (Pearce dan Robinson, 2003). Bahasa hukum di Inggris agak berbeda dengan di Amerika. Bangkrut digunakan untuk merujuk pribadi, sedang untuk perusahaan digunakan istilah insolvensi (Franksdan Sussman, 2005 dalam Priambodo, 2017).

Di Indonesia kepailitan (failure) diatur dalam UU.No.1 tahun 1998, disebutkan bahwa debitur yang mempunyai dua atau lebih kreditur dan tidak dapat membayar sedikitnya satu utang yang telah jatuh waktu dan tidak dapat ditagih, dinyatakan pailit dengan putusan pengadilan yang berwenang, baik atas permohonan sendiri, maupun atas permintaan seorang atau lebih krediturnya. Permohonan ini dapat juga diajukan oleh kejaksaan untuk kepentingan umum

\section{Model Prediksi Financial Distress}

\section{a. Model Grover}

Grover menggunakan sampel sesuai dengan model Altman Z-score pada tahun 1968, dengan menambahkan tiga belas rasio keuangan baru. Sampel yang digunakan sebanyak 70 perusahaan dengan 35 perusahaan yang bangkrut dan 35 perusahaan yang tidak bangkrut pada tahun 1982 sampai 1996. Grover (2001) menghasilkan fungsi sebagai berikut:

$$
\mathrm{G}-\text { Score }=1,650 \mathrm{X} 1+3,404 \mathrm{X} 3-0,016 \mathrm{ROA}+0,057
$$

Dimana :

$\mathrm{X} 1=$ Working capital $/$ total assets

$\mathrm{X} 3$ = Earnings before interest and taxes / total assets

$\mathrm{ROA}=$ Net income $/$ total assets 
Model Grover mengkategorikan perusahaan dalam keadaan financial distress dengan skor kurang atau sama dengan $-0,02(\mathrm{G} \leq-0,02)$. Sedangkan nilai untuk perusahaan yang dikategorikan dalam keadaan tidak mengalami financial distressadalah lebih atau sama dengan $0,01(\mathrm{G} \geq 0,01)$.

b. Model Springate

Springate (1978) telah melakukan penelitian dan menghasilkan model prediksi kebangkrutan yang dibuat mengikuti prosedur model Altman. Model Springate menggunakan 4 rasio keuangan untuk memprediksi adanya potensi kesulitan keuangan dalam suatu perusahaan. Model Springate ini dapat digunakan untuk memprediksi Financial Distress. Model ini memiliki dasar perhitungan sebagai berikut:

Dimana :

$$
\mathrm{S}-\text { Score }=1,03 \mathrm{~A}+3,07 \mathrm{~B}+0,66 \mathrm{C}+0,4 \mathrm{D}
$$

A $=$ Working capital/total assets

$\mathrm{B}=$ Net profit before interest and taxes/total assets

$\mathrm{C}=$ Net profit before taxes/current liabilities

$\mathrm{D}=$ Sales/total assets

Jika skor yang didapat $S>0,862$ maka perusahaan diklasifikasikan sehat dan jika skor $S<0,862$ maka perusahaan diklasifikasikan mengalami Financial Distress.

c. Model Zmijewski

Zmijewski(1984) menggunakan analisis rasio yang mengukur kinerja leverage, profitabilitas, serta suatu perusahaan untuk model prediksinya. Zmijewski menggunakan probit analisis yang diterapkan pada 40 perusahaan yang telah bangkrut dan 800 perusahaan yang masih bertahan saat itu. Model yang berhasil dikembangkan oleh Zmijewski yaitu (Fanny dan Saputra,2006):

$$
X=-4,3-4,5 X 1+5,7 X 2-0,004 X 3
$$

Dimana :

$\mathrm{X} 1=$ Return on Assets

$\mathrm{X} 2=$ Total debt/total assets

X3 = Current assets/current liability

Dari hasil perhitungan model Zmijewski, diperoleh nilai X-Score yang dibagi dalam dua golongan. Jika X-Score bernilai negatif $(X-S c o r e ~<0)$, maka perusahaan tersebut digolongkan dalam kondisi yang sehat. Sebaliknya jika XScore bernilai positif (X-Score $\geq 0)$ maka perusahaan tersebut dapat digolongkan dalam kondisi yang tidak sehat atau cenderung mengarah ke kebangkrutan.

\section{METODE PENELITIAN}

Jenis penelitian Penelitian ini menggunakan rancangan penelitian kuantitatif, penggunan data-data yang terukur secara tepat, yang diperoleh melalui teknik pengumpulan data melalui studi dokumentasi atas laporan keuangan perusahaan selama peiode tahun 20132016. Penelitian kuantitatif digunakan karena pendekatan ini memiliki dasar teori yang kuat sehingga mudah dalam generalisasi.

Teknik analisis data pada laporan keuangan digunakan untuk mengukur, mengetahui, menggambarkan kebangkrutan pada PT Citra Maharlika Nusantara Corpora Tbk. 
Keseluruhan data laporan keuangan pada PT Citra Maharlika Nusantara Corpora Tbk yang terdaftar di Bursa Efek Indonesia (BEI) periode 2013-2016 selanjutnya dianalisis untuk dapat memberikan data, peneliti menggunakan analisis data dengan medel pridiksi Grover, Springate, dan Zmijewski.

Setelah dilakukan perhitungan kebangkrutan menggunakan ketiga model tersebut, langkah selanjutnya yaitu menghitung tingkat akurasi guna mengetahui seberapa besar ketepatan masing-masing model dalam analisis kebangkrutan pada PT Citra Maharlika Nusantara Corpora. Menurut Altman (1968), tingkat akurasi dihitung dengan cara sebagai berikut:

$$
\text { Tingkat Akurasi }=\frac{\text { Jumlah Prediksi Benar }}{\text { Jumlah Sampel }} X 100 \%
$$

Jumlah prediksi benar yaitu jumlah periode yang dinyatakan sehat dan jika dihitung dengan model Grover, Springate dan Zmijewski.

\section{HASIL DAN PEMBAHASAN}

Pada penelitian ini menggunakan data laporan keuangan. Data tersebut diperoleh dari situs resmi Bursa Efek Indonesia (BEI). Data yang berhasil dihimpun salama 14 bulan dari periode tahun 2013-2016. Berikut ini akan ditampilkan rata-rata hasil perhitungan rasio keuangan PT. Citra Maharlika Nusantara Corpora Tbk.

Tabel 1

Statistik Deskriptif Rasio Keuangan

\begin{tabular}{|c|c|c|c|c|c|}
\hline Rasio & $\mathbf{N}$ & Minimum & Maximum & Mean & $\begin{array}{c}\text { Std } \\
\text { Devisiasi }\end{array}$ \\
\hline $\begin{array}{l}\text { Modal Kerja_Total } \\
\text { Aset }\end{array}$ & 14 & - 1,44084 & $-0,10027$ & 0,51739 & 0,46736 \\
\hline EBIT_Total Aset & 14 & $-0,58955$ & 0,14114 & 0,01194 & 0,17696 \\
\hline EBT_Hutang Lancar & 14 & $-0,65788$ & 0,23079 & 0,03252 & 0,23703 \\
\hline SALES_Total Aset & 14 & 0,10161 & 0,70324 & 0,29460 & 0,16704 \\
\hline Return On Aset & 14 & 0,10161 & 0,70324 & 0,29460 & 0,16704 \\
\hline Debt Ratio & 14 & 0,49579 & 1,67082 & 0,85402 & 0,40554 \\
\hline Current Ratio & 14 & 0,08934 & 0,59248 & 0,28117 & 0,16303 \\
\hline
\end{tabular}

Sumber data: Laporan Keuangan (2018)

Berdasarkan Tabel 1, dapat diketahui bahwa kinerja perusahaan berdasarkan rasio keuangan selama periode tahun 2013-2016 adalah nilai rata-rata modal kerja -0,51739 berarti bahwa perusahaan selama periode tersebut memiliki nilai modal kerja yang negatif, Selanjutnya rasio profitabilias berdasarkan EBIT/Total Aset memiliki rata-rata nilai negatif sebesar -0,01194 dan rasio EBIT/Hutang Lancar memiliki rata-rata nilai negatif sebesar -0,0325, dari kedua rasio profitabilitas tersebut dapat diketahui bahwa perusahan mengalami kerugian selama periode tersebut.

Selanjutnya dilakukan perhitungan prediksi financial distress pada sampel penelitian dengan model Grover, Springate dan Zmijewski.Perhitungan prediksi kebangkrutan PT Citra 


\section{NATIONALLY ACCREDITED JOURNAL - DECREE NO. 21/E/KPT/2018}

Maharlika Nusantara Corpora Tbk pada periode Juni 2013 - September 2016. Maka diperoleh hasil sebagai berikut.

Tabel 2

Hasil Analisis Model Prediksi Kebangkrutan

\begin{tabular}{|c|c|c|c|c|c|c|}
\hline \multirow{2}{*}{ Periode } & \multicolumn{2}{|c|}{ Model Grover } & \multicolumn{2}{|c|}{ Model Springate } & \multicolumn{2}{|c|}{ Model Zmijewski } \\
\hline & Nilai & Katagori & Nilai & Katagori & Nilai & Katagori \\
\hline Jun-13 & 0,24451 & Sehat & 0,46767 & Bangkrut & $-2,04721$ & Sehat \\
\hline Sep-13 & 0,36633 & Sehat & 0,62411 & Bangkrut & $-\quad 2,61145$ & Sehat \\
\hline Des-13 & 0,06190 & Bangkrut & 0,07518 & Bangkrut & - 1,67644 & Sehat \\
\hline Mar-14 & 0,08328 & Bangkrut & 0,00443 & Bangkrut & - 1,66271 & Sehat \\
\hline Jun-14 & 0,13878 & Sehat & 0,32430 & Bangkrut & $-2,45342$ & Sehat \\
\hline Sep-14 & 0,16966 & Sehat & 0,39442 & Bangkrut & $-2,95110$ & Sehat \\
\hline Des-14 & 0,54465 & Bangkrut & $-0,21108$ & Bangkrut & - 0,40019 & Sehat \\
\hline Mar-15 & 0,72323 & Bangkrut & - 0,48103 & Bangkrut & $-0,64539$ & Sehat \\
\hline Jun-15 & - 0,69506 & Bangkrut & $-0,35686$ & Bangkrut & - 1,44457 & Sehat \\
\hline Sep-15 & - 0,72944 & Bangkrut & $-0,38173$ & Bangkrut & $-2,37599$ & Sehat \\
\hline Des-15 & 3,51600 & Bangkrut & - 2,93347 & Bangkrut & - 0,77249 & Sehat \\
\hline Mar-16 & 1,68138 & Bangkrut & - 1,07391 & Bangkrut & 2,44120 & Bangkrut \\
\hline Jun-16 & 2,17859 & Bangkrut & - 1,44543 & Bangkrut & 3,05375 & Bangkrut \\
\hline Sep-16 & 2,49435 & Bangkrut & $-1,63120$ & Bangkrut & 2,92113 & Bangkrut \\
\hline
\end{tabular}

Berdasarkan hasil perhitungan Tabel 2, maka dilakukan perhitungan tingkat akurasi terhadap ketiga model. Berikut ini akan ditampilkan hasil perhitungan tingkat akurasi prediksi financial distress.

Tabel 3

Tingkat Akurasi Model Prediksi Kebangkrutan

\begin{tabular}{ccc}
\hline No & Model Prediksi & Tingkat Akurasi (\%) \\
\hline 1 & Model Grover & 71,43 \\
2 & Model Springate & 100 \\
3 & Model Zmijewski & 21,48 \\
\hline
\end{tabular}

Tabel 3 menunjukkan bahwa model prediksi Springate paling akurat dalam memprediksi kebangkrutan PT Citra Maharlika Nusantara Corpora Tbk dengan tingkat akurasi 100\%, kemudian model Grover juga memprediksi perusahaan mengalami kebangkrutan dengan nilai akurasi sebesar 71,43\%. Sedangakan tingkat akurasi terendah untuk memprediksi kebangkrutan ada pada model Zmijewski dengan nilai akurasi 21,48\%. Hasil penelitian ini mendukung hasil penelitian terdahulu dari Permana dkk (2017), Priambodo (2017) dan Sari (2014) menemukan bahwa model Springate memiliki tingkat akurasi yang paling baik diantara model lainnya.

Model Springate adalah model terbaik dan terakurat diantara model Grover dan Zmijewski dalam memprediksi kebangkrutan pada PT Citra Maharlika Nusantara Corpora 


\section{NATIONALLY ACCREDITED JOURNAL - DECREE NO. 21/E/KPT/2018}

Tbk, maka hal yang dilakukan adalah melihat kedalam komponen yang terdapat dalam model itu sendiri. Komponen tersebut dapat dilihat pada Tabel 4.

Tabel 4.

Variabel Model Grover, Springate, dan Zmijewski

\begin{tabular}{|l|c|c|c|}
\hline \multirow{2}{*}{ Variabel } & \multicolumn{3}{c|}{ Model } \\
\cline { 2 - 4 } & Grover & Springate & Zmijewski \\
\hline Modal Kerja terhadap Total Aset & Ada & Ada & Tidak Ada \\
\hline EBIT tehadap Total Aset & Ada & Ada & Tidak Ada \\
\hline EBT terhadap Total aset & Tidak Ada & Ada & Tidak Ada \\
\hline ROA & Ada & Tidak Ada & Ada \\
\hline Sales to Total Assets & Tidak Ada & Ada & Tidak Ada \\
\hline Debt Ratio & Tidak Ada & Tidak Ada & Ada \\
\hline Current Ratio & Tidak Ada & Tidak Ada & Ada \\
\hline
\end{tabular}

Rasio Modal kerja terhadap total asset menjadi salah satu rasio dalam model Springate. Modal kerja bersih diperoleh dengan cara aktiva lancar dikurangi dengan kewajiban lancar. Modal kerja bersih yang negatif kemungkinan besar akan menghadapi masalah dalam menutupi kewajiban jangka pendeknya karena tidak tersedianya aktiva lancar yang cukup untuk menutupi kewajiban tersebut. Sebaliknya, perusahaan dengan modal kerja bersih yang bernilai positif jarang sekali menghadapi kesulitan dalam melunasi kewajibannya.Kesulitan keuangan jangka pendek bersifat sementara dan belum begitu parah. Tetapi kesulitan semacam itu apabila tidak ditangani bisa berkembang menjadi kesulitan tidak solvabel (hutang lebih besar dibanding aset). Apabila tidak solvabel, perusahaan bisa dilikuidasi atau direorganisasi. Likuidasi dipilih apabila nilai likuidasi lebih besar dibandingkan dengan nilai perusahaan kalau diteruskan. Reorganisasi dipilih kalau perusahaan masih menunjukan prospek dan dengan demikian nilai perusahaan kalau diteruskan lebih besar dibandingkan nilai perusahaan kalau dilikuidasi.

Dalam setiap perusahaan membutuhkan dana atau modal kerja yang digunakan untuk membiayai kegiatan operasionalnya dan untuk mengadakan pengembangan usahanya. Modal kerja sangat penting sebagai motor penggerak didalam sistem keuangan perusahaan. mengingat pentingnya modal kerja dalam perusahaan, manajemen keuangan harus dapat merencanakan dengan baik besarnya jumlah modal kerja yang tepat dan sesuai dengan kebutuhan perusahaan karena jikaterjadi kelebihan atau kekurangan dana hal ini akan mempengaruhi tingkat profitabilitas perusahaan. Oleh karena itu, perusahaan haruslah perlu untuk mengusahakan dan menjaga keseimbangan dalam mengatur siklus perputaran modal kerja, karena didalam pengelolaan modal kerja itu sendiri ada beberapa kontradiksi yang dialami perusahaan yaitu antara modal kerja yang menitikberatkan pada usaha untuk menjaga likuiditas (Muktiadji dkk, 2007). Pentingnya likuiditas dapat dilihat dengan mempertimbangkan dampak yang berasal dari ketidakmampuan perusahaan memenuhi kewajiban jangka pendeknya (Jhon,2005). Kurangnya likuiditas menghalangi perusahaan untuk memperoleh keuntungan dari diskon atau kesempatan mendapatkan keuntungan, selain itu Jhon (2005) juga mengatakan masalah likuiditas yang lebih parah mencerminkan ketidakmampuan perusahaan untuk memenuhi kewajiban lancar. Dengan demikian masalah 


\section{NATIONALLY ACCREDITED JOURNAL - DECREE NO. 21/E/KPT/2018}

ini dapat mengarah pada penjualan investasi dan aktiva dengan terpaksa, dan dalam bentuk yang paling parah mengarah kebangkrutan.

Selanjutnya, perhitungan variable earning before interest and tax serta variable penjualan (sales) menunjukan kemampuan perusahaan dalam meningkatkan keuntungan dan penjualan dalam menjaga ketersediaan likuiditas perusahaan. Manajemen yang tidak efisien akan mengakibatkan kerugian terus- menerus yang pada akhirnya menyebabkan perusahaan tidak dapat membayar kewajibannya. Ketidakefisien ini diakibatkan oleh pemborosan dalam biaya, dan di satu sisi kurangnya keterampilan dan keahlian manajemen dalam meningkatkan strategi penjualan atau pendapatan. Kurangnya likuiditas bagi pemegang saham sering kali diawali dengan keuntungan yang rendah selain itu kekurangan likuiditas dapat mengakibatkan hilangnya pengendalian pemilik atau kerugian investasi modal. Sedangkan kurangnya likuiditas untuk kreditor perusahaan dapat menyebabkan penundaan pembayaran bunga dan pokok pinjaman atau bahkan tidak dapat ditagih sama sekali bahkan pelanggan dan pemasok produk dan jasa perusahaan merasakan juga masalah likuiditas jangka pendek. Implikasinya antara lain mencakup ketidakmampuan perusahaan untuk memenuhi kontrak serta merusak hubungan dengan pelanggan dan pemasok penting.

\section{KESIMPULAN, IMPLIKASI DAN KETERBATASAN PENELITIAN}

Penelitian ini bertujuan untuk menganalisis bagaimana hasil dari model Grover, Springate dan Zmijewski dalam memprediksi kebangkrutan PT Citra Maharlika Nusantara Corpora Tbk periode Juni 2013 - September 2016 serta mengukur tingkat akurasi model prediksi kebangkrutan tersebut dan menentukan model prediksi manakah diantara ketiga model tersebut yang paling akurat. Model Springate menjadi model prediksi paling akurat dengan tingkat akurasi 100\% untuk memprediksi kebangkrutan PT Citra Maharlika Nusantara Corpora Tbk dibandingakan dengan model Grover dengan tingkat akurasi 71,48\% dan model Zmijewski dengan tingkat akurasi paling rendah sebesar 21,48\%. Hasil penelitian ini mengindikasikan bahwa sektor industri usaha harus memperhatikan kemampuan dalam pengelolaan modal kerja perusahaan dalam rangka menjaga likuiditas perusahaan, selain itu meningkatkan penjualan dan pendapatan serta efisiensi biaya operasional dan pengelolaan piutang usaha yang baik dapat meningkatkan earning akan berdampak pada ketersediaan modal kerja sehingga kemungkinan kesulitan keuangan akan dapat diantisipasi. Keterbatasan dalam penelitian ini terdapat pada pengujian tiga model dengan melibatkan satu perusahaan dalam satu sektor usaha saja, kedepan dapat melakukan pengujian model lainnya seperti pengujian model arus kas logistical dari Ohlson dan melibatkan tidak hanya satu sektor usaha saja, sehingga menciptakan model yang fleksibel untuk segala sektor usaha. 


\section{DAFTAR PUSTAKA}

Almilia, L. S., dan Kristijadi, E. (2003). Analisis Rasio Keuangan Untuk Memprediksi Kondisi Financial Distress Perusahaan Manufaktur Yang Terdaftar Di Bursa Efek Jakarta.JurnalAkuntansi dan Auditing Indonesia (JAAI) Vol. 7 No. 2, Desember 2003 ISSN: 1410-2420. STIE Perbanas. Surabaya.

Altman, E. L. (1968). Financial Ratios,Discriminant Analysis and the Prediction of Corporate Bankruptcy. The Journal of Finance, Vol. 23.

Anonim (2017). Laporan Keuangan dan Tahunan. www.idx.co.id. Diakses pada 25 September 2017.

Anonim, (2018). http :www.kabar24.com[diakses : 15 Desember 2018]

Anonim, (2018). http :www.wikipedia.com[diakses : 15 Desember 2018]

Anonim. (1998). UU No.10 tahun 1998, Tentang Perubahan Terhadap UU No. 7 tahun 1992, Jakarta.

Atmini, S., dan Wuryana. (2005). Manfaat Laba dan Arus Kas untuk Memprediksi Kondisi Financial Distress pada Perusahaan Tekstile Mill dan Apparel and Other Textile Products terdaftar di Bursa Efek Jakarta. Simposium Nasional Akuntansi VIII, Solo, Hal. 460-474.

Bimawiratma, P. G., (2016). Analisis Akurasi Model Altman, Grover, Springate, dan Zmijewski dalam Memprediksi Perusahaan Delisting pada Perusahaan Manufaktur di Bursa Efek Indonesia Periode 2009-2013.Skripsi. Universitas Sanata Dharma Yogyakarta

Brigham dan Huston. (2010). Dasar-dasar Manajemen Keuangan Buku 1 (Edisi 11). Jakarta: Salemba Empa

Brigham, F. and Gapenski. (1997). Financial Management: The.ory and Practice.(Fort Worth: The Dryden Press

Elloumi, F. and Gueyie, J. P., (2001). Financial Distress and Corporate Governance:an Empirical Analysis. CorporateGovernance. Bedford: 1(1): 15-23.

Fatmawati, M. (2012). Penggunaan Zmijewski Model, The Altman Model, dan The Springate Model Sebagai Prediktor Delisting. Jurnal. Universitas Muhammadiyah Metro.

Hadi, S. dan Anggraeni, A., (2008). Pemilihan Prediktor DelistingTerbaik (Perbandingan Antara The Zmijewski Model, The Altman Model,dan The Springate Model)

John J, W., (2005). Analisa Laporan Keuangan, Buku Dua, diterjemahkan Oleh Yanivi S. Yogyakarta: Salemba Empat.

Kasmir., (2012). Analisis Laporan Keuangan, PT Raja Grafindo persada. Jakarta.

Muktiadji, N., dan Soemantri, S., (2009). Analisis Pengaruh Biaya Produksidalam Peningkatan Kemampulabaan Perusahaan: Studi Kasus di PT HMSampoerna Tbk. Jurnal Ilmiah Kesatuan. Nomor 1, Volume 11. Jakarta.

Munawir ,S. (2002). Analisa Laporan Keuangan, Edisi Keempat, Cetakan Ketiga Belas. Yogyakarta: Liberty.

Pearce, J. A. Dkk (2003). Strategic Management Formulation, Implementation and Control. Mc Graw hill, Boston.

Permana, dkk. (2017). Prediksi Financial Distress pada Perusahaan Manufaktur di Bursa Efek Indonesia. Jurnal Bisnis dan Manajemen. Vol.7, No.2:149-166

Priambodo, D. (2017). Analisis Perbandingan Model Altman, Sprintgate, Grover dan Zmijewski Dalam Memprediksi Financial Distress (Studi Empiris Pada 
Perusahaan Sektor Pertambangan yang Terdaftar di Bursa Efek Indonesia Periode 2012-2015). Skripsi. Fakultas Ekonomi Universitas Negeri Yogyakarta

Prihantini, dkk., (2013). PrediksiKebangkrutan denganModel Grover, AltmanZ-score, Springate dan Zmijewski pada PerusahaanFoodand Beverages diBursaEfek Indonesia.E-Jurnal. Akuntansi Universitas Udayana.

Sari, E W P., (2014). Penggunaan Model Zmijewski, Springate, Altman Z-Score dan Grover dalam Memprediksi Kepailitan pada Perusahaan Transportasi yang Terdaftar di BEI. Skripsi. Universitas Dian Nuswantoro.

Springate, G. L.V. (1978). Predicting The Possibility of Failure in a Canadian Firm. Unpublised Masters Thesis. Simon Fraser University. January 1978. 